\title{
Conflicts of Interest in Financial Distress: The Role of Employees
}

\author{
Wenchien $\mathrm{Liu}^{1}$ \\ ${ }^{1}$ Department of Finance, Chung Yuan Christian University, Taoyuan, Taiwan, R.O.C. \\ Correspondence: Wenchien Liu, Department of Finance, Chung Yuan Christian University, 200 Chung Pei Road, \\ Chung Li District, Taoyuan City, Taiwan 32023, R.O.C. Tel: 886-3-265-5706. E-mail: wcliu@cycu.edu.tw
}

Received: September 30, 2017

Accepted: October 25, 2017

Online Published: November 10, 2017

doi:10.5539/ijef.v9n12p101

URL: https://doi.org/10.5539/ijef.v9n12p101

\begin{abstract}
The interests of employees are not consistent with those of other stakeholders when firms are in financial distress. Hence, conflicts of interest among stakeholders are more severe, especially for those firms with strong union power, as news is reported in the media. However, little attention has been paid to the impacts of employees on bankruptcy resolutions. This study examines the impacts of employees (i.e., union power) on the conflicts of interest of distressed firms in the United States from 1983 to 2015. We find that union power has strong effects on conflicts of interest related to employees, such as asset sales, debtor-in-possession financing, successful emergence from bankruptcy, and CEO replacement. On the contrary, for conflicts of interest unrelated to employees, including the choice of bankruptcy resolution method, and conflicts of interest between creditors and debtors, we find no significant relationships. Finally, we also find a positive impact of union power on the probability of refiling for bankruptcy in the future after emerging successfully.
\end{abstract}

Keywords: financial distress, union power, bankruptcy resolution, conflicts of interest

Citation: ....... "Many factors are acknowledged as contributing to GM's decline: it juggled too many brands, over-extended its dealer network, failed to respond rapidly to market cues, and struggled to work with its union, the United Auto Workers (UAW).........Labor costs for a typical UAW worker at a GM plant were by some estimates $\$ 73$ per hour - compared to the $\$ 44$ per hour for workers at non-unionized Toyota and Honda plants in the U.S. Or take the infamous "jobs bank": surplus workers, rather than getting laid off, would receive 95\% of their full salaries plus benefits while the company waited to reassign them. .....A worker might be able to retire in his early 50s and collect an annual pension of \$37,500, paid wholly by GM. By 2008 there were 4.6 retired GM employees for each active worker. "........

Source: Doug Altner,“What Explains GM's Problems With The UAW?”Fortune, May 20, 2013.

\section{Introduction}

Conflicts of interest among stakeholders such as equity-holders, creditors, managers, employees, customers, and suppliers are vital issues in corporate finance, especially as these conflicts are more severe when firms are in financial distress. Furthermore, what are the effects of each stakeholder on bankruptcy resolution? Who can help alleviate the conflicts of interest among them? Who would make the problems worse? These are important problems that demand more attention. The number of studies of the role of bankruptcy resolution is rising rapidly in the literature. However, most focus on the roles of equity-holders, creditors, and managers, while very few attempts have been made to examine the role of employees. Hence, this study investigates the effects of employee force on conflicts of interest and bankruptcy resolutions when firms are in financial distress or go bankrupt.

The importance of conflicts of interest and bankruptcy resolutions when firms are in financial distress cannot be overemphasized for the following reasons. First, successful reorganization that helps a firm emerge from financial distress would benefit several stakeholders and the whole economy, such as employees avoiding unemployment, creditors lowering the loss of default, equity-holders escaping the threat of delisting, upstream suppliers easing the impacts of business connections, and the whole economy continuing to grow. However, if the degree of financial distress a firm faces is severe, applying liquidation directly may effectively reduce the loss compared with survival or reorganization. Take the well-known bankruptcy case of Eastern Airlines for example. Weiss and Wruck (1998) illustrate that the overprotection of this distressed firm ultimately resulted in a further loss of $50 \%$ of its asset value. Hence, choosing an efficient way in which to solve conflicts of interest 
under financial distress needs to be examined and discussed, especially the role of employees (or unions), as shown in the citation case of GM in the beginning of this paper. Lastly, this is an important issue related not only to the field of finance but also to labor economics and bankruptcy law.

Therefore, this study examines the impacts of employees on conflicts of interest and bankruptcy resolutions for distressed firms in the United States. We address the following three research questions specifically. First, for conflicts of interest directly related to employees including asset sales, debtor-in-possession (DIP) financing, emerging successfully, CEO replacement, and the costs of bankruptcy resolution, what are the impacts of union power on these bankruptcy resolutions? Second, for conflicts of interest unrelated to employees such as the choice of bankruptcy resolution method, absolute priority rule (APR) violations, agent assignment for equity-holders, agent assignment for creditors, and forum shopping, what are the impacts of union power on these bankruptcy resolutions? Third, what are the impacts of union power on firms' long-term performance after emerging successfully? That is, do distressed firms refile for bankruptcy or not? With these questions in mind, our research results may not only help understand conflicts of interest for those distressed firms, but also help find better bankruptcy resolutions to raise the benefits for each stakeholder.

Overall, our empirical results are consistent with our inferences. First, we find that distressed firms with stronger union power face lower asset sales, more DIP financing, higher chances of emerging successfully, more CEO replacement, and higher costs of bankruptcy resolution, which illustrates that employees have significant impacts on conflicts of interest directly related to themselves. We also find that employees of distressed firms do not seem to care about conflicts of interest unrelated to themselves, such as the choice of bankruptcy resolution method, APR violations, agent assignment for equity-holders, agent assignment for creditors, and forum shopping. Finally, regarding distressed firms' long-term performance after emerging, we find a positive relationship between union power and the probability of refiling.

Over the past few decades, a considerable number of related studies have been conducted; however, no study has thus far tried to answer our research questions directly. Overall, we contribute to three streams of the literature. The first strand of the literature is on the effects of distressed firms' stakeholders on conflicts of interest and bankruptcy resolution, such as the roles of equity-holders, creditors, and managers. Taking the role of equity-holders for example, Hotchkiss and Mooradian (1997) focus on the effects of vulture investors on the post-organization performance of distressed firms. Hotchkiss, Smith, and Stromberg (2014) find that private equity backed firms are less likely to default and resolve fairly efficiently. Jiang, Li, and Wang (2012) examine the effects of hedge funds on mitigating conflicts among different classes of claims, alleviating financial constraints, and value creation. Further, Demiroglu and James (2015) find that bank loans have different effects on troubled debt restructurings when they are diffusely held or securitized. Ivashina, Iverson, and Smith (2016) find that the degree of debt ownership concentration affects bankruptcy outcomes and the probability of liquidation. Both these studies point out that the role of creditors is also an essential part for the determinants of distressed firms' conflicts of interest and bankruptcy resolution. Hence, although studies have investigated the roles of equity-holders, creditors, and managers, what seems to be lacking is the role of employees, which we examine in this study.

The second strand of the literature concerns the negative impacts on firms' stakeholders when firms go bankrupt. Both Gilson (1990) and James (1995) find that the equity-holders of distressed firms experience significant ownership loss during that process. Gilson (1989), Betker (1995), and Ayotte and Morrison (2009) provide evidence that managers face the threat of CEO replacement. In addition, Acharya, Bharath, and Srinivasan (2007), Donovan, Frankel, and Martin (2015), and Carrizosa and Ryan (2015) investigate the various kinds of creditor right losses for debt-holders when firms file for bankruptcy, such as low recovery rates, APR violations, and asset sales. To sum up, several studies have examined the negative impacts for distressed firms' managers, equity-holders, and creditors. However, little attention has been paid to the losses of employees. In this study, we bridge this gap in the literature.

The third strand of the literature concerns the effects of employee force on the stock market reaction, firm performance, and financial policy, which usually measure employee force by union power. We first discuss studies of the stock market reaction. Ruback and Zimmerman (1984) find that the stock market reaction to the establishment of firms' unions in the United States is significantly negative on average. Abowd (1989) focuses on wage bargaining and finds identical negative reactions. Lee and Mas (2012) focus on the long-run impacts of union establishment and find that the stock market reaction is insignificant in the short run but significantly negative in the long run. Then, regarding empirical evidence of firm performance, Hirsch (1991) finds that the relationship between union power and firm performance is negative, using data on 705 U.S. industrial firms in the 1970s. Faleye, Mehrotra, and Morck (2006) view the equity ownership of labor as a voice in corporate 
governance. They find that this may result in conflicts of interest between employees and shareholders, which decreases firm value. Lastly, numerous studies examine the relation between employees and financial policy, such as capital structure policy (Bronars \& Deere, 1991; Hanka, 1998), liquidity policy (Masta, 2010; Klasa, Maxwell, \& Ortiz-Molina, 2009; Schmalz, 2013), dividend policy and repurchase (DeAngelo \& DeAngelo, 1991, 1994; Chen, Chen, \& Wang, 2015), and compensation policy (Huang et al., 2017). Overall, although concern about union power has been growing in recent years, the impacts of union power on financial distress has not been studied so far. This is another contribution of this study to the literature.

\section{Method}

\subsection{Research Framework and Data Source}

This study investigates the impacts of employee force on conflicts of interest to answer the following three research questions: What are the impacts of union power on bankruptcy resolutions for conflicts of interest related and unrelated to employees? What are the impacts of union power on firms' long-term performance after emerging? To fully explore bankruptcy cases, we choose 1,012 U.S. listed firms filing for bankruptcy from 1980 to 2015 in the UCLA-LoPucki Bankruptcy Research Database (BRD) as our research target. Figure 1 depicts the time series pattern of bankrupt firms. We also supplement some measures or double check the bankruptcy resolutions from other databases, such as SEC Edgar filing, BankruptcyData.com of New Generation Research, and Public Access to Court Electronic Records (PACER). In addition, regarding the measures of employee force, we follow Masta (2010) and Huang et al. (2017) to adopt union power as a proxy. The sources of these data include the Union Membership and Coverage Database from the CPS, SEC Edgar filing, BRD, and National Labor Relations Board. We explain the detailed definitions of each variable in the following subsections. In Sections 2.2 to 2.4, we illustrate the three groups of main variables used in this study, including the measure of bankruptcy resolution, the measure of union power (proxy for employee force), and a set of control variables. Then, Section 2.5 demonstrates the setting of our empirical model.

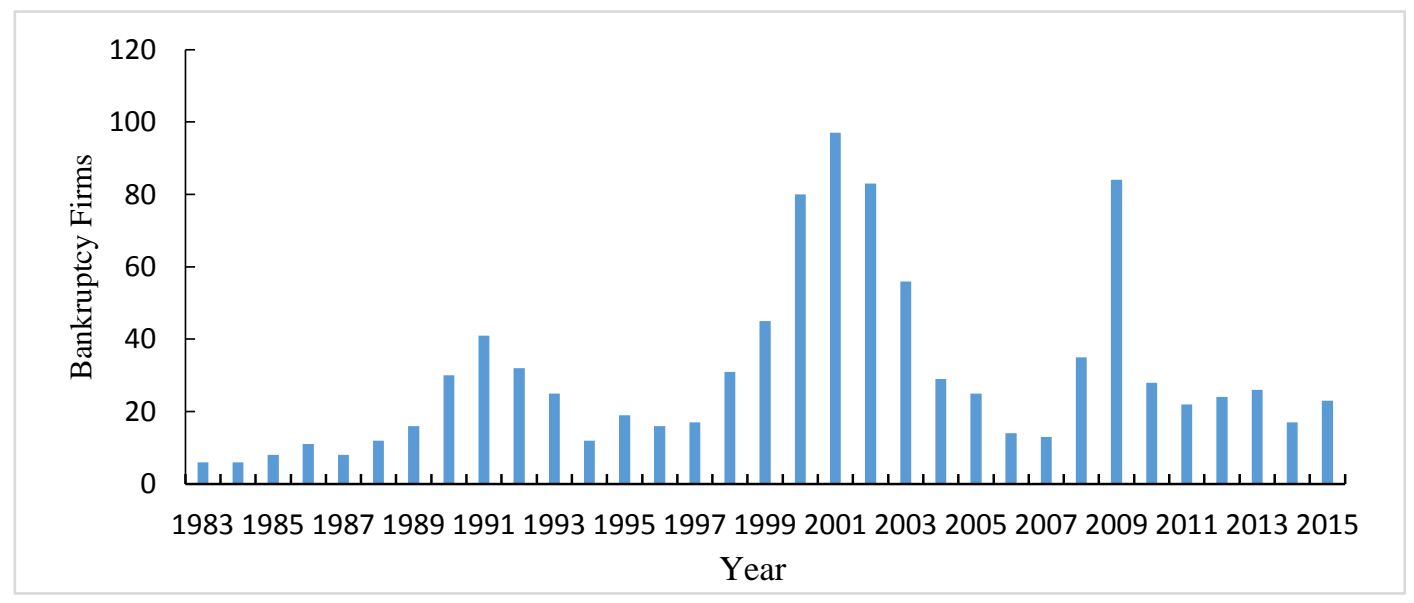

Figure 1. Bankrupt firms distribution

\subsection{Measure for Bankruptcy Resolutions}

Based on our research questions, we construct three measures of bankruptcy resolutions: bankruptcy resolutions directly related to the conflicts of interest of employees, bankruptcy resolutions unrelated to the conflicts of interest of employees, and distressed firms' long-term performance after emerging. For the first measure of bankruptcy resolutions, we collect five indexes. The first one is a dummy for passing 363 sale plans (ASale363DM). The second one is a dummy for DIP financing (DIPFinaDM), which means distressed firms receiving DIP financing. The third one is the success of emerging from bankruptcy through a Chapter 11 reorganization plan (EmergingSucDM). The fourth one is a dummy for CEO replacement (CEOReplaceDM). The final one comprises two measures of the costs of bankruptcy resolution: the cost of time spent on the bankruptcy process (CostOfBKTime) and the cost of fees spent on bankruptcy filing (CostOfBKFee).

Next, for the second group of bankruptcy resolutions unrelated to the conflicts of interest of employees, we constructed the following two groups of measures. The first one is the choice of bankruptcy resolution method subdivided into three dummies: choosing the resolution method of prepackaged procedure (ChoiceOfPackDM), 
prenegotiated procedure (ChoiceOfNegoDM), and free fall procedure (ChoiceOfFrFaDM). The second one is conflicts of interest purely between the creditor and debtor, which are not related to employees, including the degree of APR violations (ConflictsAPRDegr), a dummy for APR violations (ConflictsAPRDM), agent assignment for equity-holders (ConflictsCEquDM), agent assignment for secured creditors (ConfilictsClAgDM), agent assignment for unsecured creditors (ConflictsCredDM), and a dummy for the behavior of forum shopping (ConfilictsShopDM).

Finally, the last measure of bankruptcy resolution is distressed firms' long-term performance after emerging, for which we construct two measures. The first one is whether this firm refiles for bankruptcy after its last filing $($ RefileDM) and the second one is whether this firm refiles for bankruptcy within five years of its last filing $($ Refile5DM). We expect that the higher the union power of those distressed firms, the higher their probability of refiling for bankruptcy. Table 1 presents the summary statistics of all the bankruptcy resolution variables used in this study.

Table 1. Summary statistics for bankruptcy resolutions

\begin{tabular}{|c|c|c|c|c|c|c|c|c|}
\hline Variables & Obs. & Mean & S.D. & Min & Q1 & Median & Q3 & Max \\
\hline \multicolumn{9}{|l|}{ Panel A. Asset Sale } \\
\hline AssetSale363DM & 990 & 0.21 & 0.41 & 0 & 0 & 0 & 0 & 1 \\
\hline \multicolumn{9}{|l|}{ Panel B. DIP Financing } \\
\hline DIPFinDM & 804 & 0.67 & 0.47 & 0 & 0 & 1 & 1 & 1 \\
\hline \multicolumn{9}{|l|}{ Panel C. Emerging Success } \\
\hline EmergingSucDM & 972 & 0.69 & 0.46 & 0 & 0 & 1 & 1 & 1 \\
\hline \multicolumn{9}{|l|}{ Panel D. CEO Replacement } \\
\hline CEOReplaceDM & 952 & 0.67 & 0.47 & 0 & 0 & 1 & 1 & 1 \\
\hline \multicolumn{9}{|c|}{ Panel E. Costs of Bankruptcy Resolution } \\
\hline CostOfBKTime (days) & 986 & 530.48 & 521.22 & 9 & 181.75 & 394.00 & 691.25 & 4468.00 \\
\hline CostOfBKFee ( $\$$ billions) & 151 & 56.84 & 94.67 & 1.05 & 9.54 & 20.78 & 63.27 & 589.00 \\
\hline \multicolumn{9}{|c|}{ Panel F. Choice of Bankruptcy Resolution } \\
\hline ChoiceOfPackDM & 1012 & 0.10 & 0.30 & 0 & 0 & 0 & 0 & 1 \\
\hline ChoiceOfNegoDM & 1012 & 0.19 & 0.39 & 0 & 0 & 0 & 0 & 1 \\
\hline ChoiceOfFrFaDM & 1012 & 0.71 & 0.46 & 0 & 0 & 1 & 1 & 1 \\
\hline \multicolumn{9}{|c|}{ Panel G. Interests Conflicts between Creditor and Debtor } \\
\hline ConflictsAPRDegr & 119 & 1.38 & 7.39 & 0 & 0.08 & 0.34 & 0.90 & 80.37 \\
\hline ConflictsAPRDM & 119 & 0.19 & 0.40 & 0 & 0 & 0 & 0 & 1 \\
\hline ConflictsCEquDM & 872 & 0.17 & 0.37 & 0 & 0 & 0 & 0 & 1 \\
\hline ConfilictsClAgDM & 341 & 0.94 & 0.25 & 0 & 1 & 1 & 1 & 1 \\
\hline ConflictsCredDM & 970 & 0.85 & 0.36 & 0 & 1 & 1 & 1 & 1 \\
\hline ConfilictsShopDM & 1011 & 0.63 & 0.48 & 0 & 0 & 1 & 1 & 1 \\
\hline \multicolumn{9}{|c|}{ Panel H. Long Term Performance after Emerging } \\
\hline RefileDM & 1012 & 0.14 & 0.35 & 0 & 0 & 0 & 0 & 1 \\
\hline Refile 5DM & 997 & 0.10 & 0.30 & 0 & 0 & 0 & 0 & 1 \\
\hline
\end{tabular}

\subsection{Measure for Employee Force (Union Power)}

The central objective of this study is to examine the impacts of employee force on the conflicts of interest of distressed firms from 1983 to 2015 in the United States. Hence, the measure of employee force is decided first. We follow the literature by adopting union power as the proxy for employee force, often measured by using the number of union members. Based on the consideration of robustness, we construct three measures: firm-level union power, which is the ratio of union members to the total employees of a firm (UnionPowerFirm), industry-level union power, which is the ratio of union members to the total employees of an industry (UnionPowerIndustry), and a dummy for union collective bargaining with its firm or employer (UnionPowrColBarDM). In order to save space, we only report the results using firm-level union power, and the robustness checks for the other two measures will be provided upon request. Figure 2 illustrates the change in union power from 1983 to 2015 in the United States. We see that the pattern for the rate of union power is unstable over these years. The summary statistics of these three measures of union power are shown in Panel A of Table 2. The summary statistics of the first two measures (firm-level and industry-level union power) are identical, implying the robustness of these two measures. 


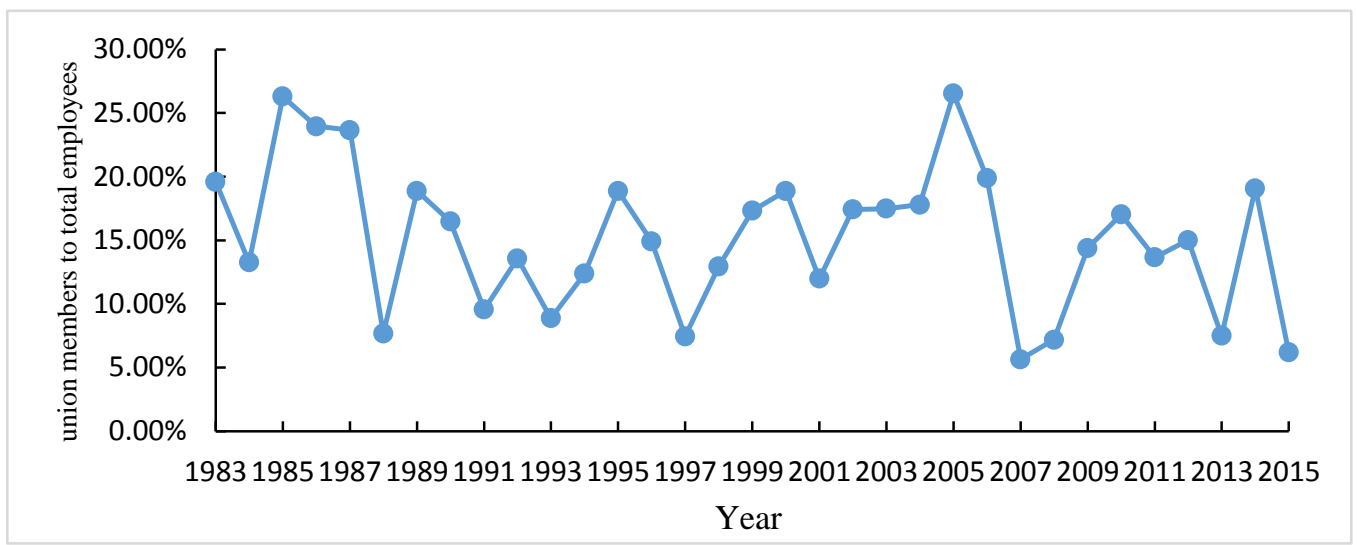

Figure 2. The change in union power from 1983 to 2015

\subsection{Control Variables}

To avoid the problem of endogeneity from missing explanatory variables, we also include those control variables highly associated with the relationship between union power and bankruptcy resolution related to the conflicts of interest of distressed firms. The first set of control variables concerns the firm's characteristics one year before filing for bankruptcy, including firm size (FirmSize), earnings before interest and tax (EBIT), total debt (Debt), and sales (Sales). The second set of control variables is related to the macroeconomic, credit market, and stock market conditions under filing for bankruptcy, such as GDP growth rate (GDPGrowth), credit spread (BAA corporate bond yield minus AAA corporate bond yield; CreditSpread), term spread (10-year Treasury yield minus two-year Treasury yield; TermSpread), and CBOE volatility index (VIX). Lastly, we also add two groups of fixed effect dummies to control for other unobservable characteristics, including year dummies to control for time fixed effects (Year Dummies) and Fama and French industry dummies to control for industry fixed effects ( $F \& F$ Industry Dummies). We report the summary statistics of these two sets of control variables in Panel B and Panel C of Table 2, respectively.

Table 2. Summary statistics for union power, firm characteristics, and macroeconomic condition

\begin{tabular}{lcccccccc}
\hline Variable & Obs. & Mean & S.D. & Min & Q1 & Q2 & Q3 & Max \\
\hline Panel A. Union Power Measurement & & & & & & & & \\
UnionPowerIndustry (\%) & 967 & 0.15 & 0.24 & 0.00 & 0.00 & 0.01 & 0.21 & 0.92 \\
UnionPowerFirm (\%) & 823 & 0.12 & 0.11 & 0.00 & 0.03 & 0.08 & 0.19 & 0.71 \\
UnionPowrColBarDM & 1012 & 0.03 & 0.16 & 0.00 & 0.00 & 0.00 & 0.00 & 1.00 \\
Panel B. Control Variable: Firm Characteristics & & & & & & & \\
FirmSize & 1012 & 3.33 & 24.99 & 0.13 & 0.34 & 0.60 & 1.58 & 691.06 \\
EBIT & 983 & 0.02 & 1.57 & -11.98 & -0.04 & 0.00 & 0.03 & 45.82 \\
Debt & 993 & 3.31 & 24.51 & 0.02 & 0.31 & 0.60 & 1.57 & 668.57 \\
Sales & 1011 & 1.60 & 6.70 & 0.00 & 0.25 & 0.50 & 1.15 & 148.98 \\
Panel C. Control Variable: Macroeconomic and Credit Market Condition & & & & & \\
GDPGrowth & 961 & 0.01 & 0.01 & -0.02 & 0.01 & 0.01 & 0.01 & 0.02 \\
CreditSpread & 1012 & 1.13 & 0.57 & 0.55 & 0.79 & 0.93 & 1.28 & 3.38 \\
TermSpread & 1012 & 1.25 & 0.92 & -1.14 & 0.39 & 1.45 & 2.01 & 2.83 \\
VIX & 924 & 22.49 & 8.17 & 10.63 & 16.74 & 21.48 & 25.92 & 59.89 \\
\hline
\end{tabular}

\subsection{Model Specification}

To examine the impacts of union power on bankruptcy resolutions, we mainly employ the following two estimation methods: ordinary least squares (OLS) and the Logit regression model. These depend on the properties of our dependent variables in each estimation. That is, if the dependent variable is a binary variable, we use the Logit estimation; otherwise, we use OLS. Hence, we construct our main baseline regression model as follows: 


\section{BankruptcyResolutions $=\alpha+\beta \cdot$ UnionPower $+\gamma_{1} \cdot$ FirmSize $+\gamma_{2} \cdot$ EBIT $+\gamma_{3} \cdot$ Debt $+\gamma_{4} \cdot$ Sales \\ $+\gamma_{5} \cdot$ GDPGrowth $+\gamma_{6} \cdot$ CreditSpread $+\gamma_{7} \cdot$ TermSpread $+\gamma_{8} \cdot$ VIX \\ $+\Gamma \cdot$ YearDummies $+\Phi \cdot F \&$ FIndustryDummies $+\varepsilon$}

where BankruptcyResolutions is used to proxy for the conflicts of interest of distressed firms, which can be divided into three groups based on our three research questions. That is, this variable is a function of the following 21 bankruptcy resolution indexes. The first group is bankruptcy resolutions directly related to the conflicts of interest of employees, including the debtor sale intended dummy (SaleIntendedDM), a dummy for asset demand from other entities (ASaleDemDM), a dummy for passing 363 sale plans (ASale363DM), days for using the 363 sale plans to sell assets (ASale363Days), a dummy for a judge passing the asset plan (ASaleDM), DIP financing (DIPFinaDM), the success of emerging from bankruptcy through a Chapter 11 reorganization (EmergingSucDM), a dummy for CEO replacement (CEOReplaceDM), the cost of time spent on the bankruptcy process (CostOfBKTime), and the cost of fees spent on bankruptcy filing (CostOfBKFee). The second group is bankruptcy resolutions unrelated to the conflicts of interest of employees, including choosing the resolution method of prepackaged procedure (ChoiceOfPackDM), prenegotiated procedure (ChoiceOfNegoDM), free fall procedure (ChoiceOfFrFaDM), degree of APR violations (ConflictsAPRDegr), a dummy for APR violations (ConflictsAPRDM), agent assignment for equity-holders (ConflictsCEquDM), agent assignment for secured creditors (ConfilictsClAgDM), agent assignment for unsecured creditors (ConflictsCredDM), and a dummy for the behavior of forum shopping (ConfilictsShopDM). Finally, the last measure of bankruptcy resolution is distressed firms' long-term performance after emerging, including whether this firm refiles for bankruptcy after last filing (RefileDM) and whether this firm refiles for bankruptcy within five years of its last filing (Refile5DM).

In addition, the variable UnionPower is used to proxy for employee force, which is also a functional variable that contains firm-level union power (UnionPowerFirm), industry-level union power (UnionPowerIndustry), and the dummy for union collective bargaining with firm or employer (UnionPowrColBarDM).

Lastly, we also control the firm, macroeconomic, and industry characteristics one year before filing for bankruptcy, including firm size (FirmSize), earnings before interest and tax (EBIT), total debt (Debt), sales (Sales), the GDP growth rate (GDPGrowth), credit spread (CreditSpread), term spread (TermSpread), and CBOE volatility index $(V I X)$. Moreover, we add two groups of dummies to control for other unobservable characteristics, including year dummies to control for time fixed effects (Year Dummies) and Fama and French industry dummies to control for industry fixed effects ( $F \& F$ Industry Dummies). As they are groups of fixed effect dummies, their associated coefficients are captured by the vectors $\Gamma$ and $\Phi$, respectively.

\section{Results and Discussion}

In this study, we examine conflicts of interest when firms are in financial distress, especially focusing on the role of employee force. Hence, we first adopt union power to proxy for employee force. Then, we classify the bankruptcy resolutions of distressed firms into three main groups to proxy for conflicts of interest, namely conflicts of interest directly related to employees, conflicts of interest unrelated to employees, and firms' long-term performance after emerging. Finally, we run the OLS and Logit regression to investigate the impacts of union power on these three groups of conflicts of interest. We present their empirical results in Sections 3.1 to 3.3 .

\subsection{Impacts of Union Power on the Conflicts of Interest Directly Related to Employees}

Employees care about several benefits such as salary, compensation, work environment, promotion, pension, and unemployment risk. In particular, when firms are in financial distress, employees may behave more aggressively to pursue their personal interests, which may collide with the interests of other stakeholders such as managers, equity-holders, and creditors. For example, they may try to fight other stakeholders to defend their jobs, ask for better severance pay, or look for a better manager. Hence, when firms are in financial distress, conflicts of interest directly related to employees will be more prominent. To raise the probability of successful reorganization to keep their jobs, employees of a distressed firm with strong union power may try to prevent the firm's assets from been sold, help their firm obtain DIP financing, raise the probability of emerging successfully, and push or force the replacement of CEOs. Further, they may aggressively pursue their personal benefits, which may result in higher costs for their firms such as attorney and accounting fees and time processing costs. Sections 3.1.1 to 3.1.5 show the results of the impacts of union power on conflicts of interest directly related to employees, including asset sales, DIP financing, emerging successfully, CEO replacement, and the costs of bankruptcy resolutions. That is, we discuss those bankruptcy resolutions directly related to the interests of employees, which may be in conflict with other stakeholders such as equity-holders, creditors, and managers in 
this section.

\subsubsection{Asset Sales}

Column (1) of Table 3 shows the initial result of regressing asset sales (ASale363DM) on the union power variable (UnionPowerFirm), which does not control for any firm characteristics, macroeconomic, or industry variables. Its coefficient is significantly negative at the 5\% level, implying that an increase in union power lowers the probability of asset sales. Column (2) shows that when those four firm characteristics variables are controlled for, the coefficient of union power is still identical to the one in column (1), which only changes from -0.788 to -0.847 with robust $t$-statistics of -2.009 and -2.121 , respectively. Then, in addition to controlling for firm characteristics, we control for macroeconomic and credit market conditions in column (3). Again, we find that its coefficient is still identical, showing robustness in our study. Finally, column (4) further controls for the year dummies and industry dummies, showing only a minor change in the coefficient of union power. That is, even when gradually adding all kinds of control variables, the coefficients of union power are identical in columns (1) to (4), showing the robustness of its negative impact on conflicts of interest over asset sales. Therefore, when firms are in financial distress, employees with strong union power lower the probability of asset sales to protect their rights.

Table 3. Effects of union power on asset sales

\begin{tabular}{|c|c|c|c|c|}
\hline & (1) & (2) & (3) & (4) \\
\hline Model & Logit & Logit & Logit & Logit \\
\hline Dependent Variable & ASale363DM & ASale363DM & ASale363DM & ASale $363 D M$ \\
\hline \multirow[t]{2}{*}{ UnionPowerFirm } & $-0.788 * *$ & $-0.847 * *$ & $-0.819 * *$ & $-0.871 * *$ \\
\hline & $(-2.009)$ & $(-2.121)$ & $(-2.022)$ & $(-2.036)$ \\
\hline \multirow[t]{2}{*}{ FirmSize } & & -0.023 & -0.024 & -0.018 \\
\hline & & $(-1.320)$ & $(-1.380)$ & $(-0.929)$ \\
\hline \multirow[t]{2}{*}{ EBIT } & & 0.050 & 0.071 & 0.022 \\
\hline & & $(0.662)$ & $(0.951)$ & $(0.263)$ \\
\hline \multirow[t]{2}{*}{ Debt } & & 0.023 & 0.022 & 0.020 \\
\hline & & $(1.377)$ & $(1.240)$ & $(1.026)$ \\
\hline \multirow[t]{2}{*}{ Sales } & & 0.013 & 0.015 & 0.010 \\
\hline & & (1.042) & (1.134) & $(0.592)$ \\
\hline \multirow[t]{2}{*}{ GDPGrowth } & & & -19.872 & -4.956 \\
\hline & & & $(-1.272)$ & $(-0.321)$ \\
\hline \multirow[t]{2}{*}{ CreditSpread } & & & -0.301 & -0.235 \\
\hline & & & $(-1.207)$ & $(-0.955)$ \\
\hline \multirow[t]{2}{*}{ TermSpread } & & & -0.017 & -0.175 \\
\hline & & & $(-0.164)$ & $(-1.608)$ \\
\hline \multirow[t]{2}{*}{$V I X$} & & & $0.031 * *$ & $0.032 * *$ \\
\hline & & & $(2.177)$ & $(2.185)$ \\
\hline \multirow[t]{2}{*}{ Constant } & $-1.207 * * *$ & $-1.189 * * *$ & $-1.298 * * *$ & $-1.277 * *$ \\
\hline & $(-12.907)$ & $(-12.393)$ & $(-3.010)$ & $(-2.513)$ \\
\hline Year Dummies & No & No & No & Yes \\
\hline$F \& F$ Industry Dummies & No & No & No & Yes \\
\hline$N$ & 946 & 917 & 862 & 845 \\
\hline pseudo $R^{2}$ & 0.005 & 0.010 & 0.021 & 0.069 \\
\hline
\end{tabular}

Note. This table reports the effects of union power on asset sale for those bankruptcy firms. The dependent variables is asset sale dummy $(A S a l e 363 D M)$. The key independent variable used to measure firm level union power is the ratio of union members to total employees (UnionPowerFirm). We also control firm characteristics one year before filing bankruptcy, including firm size (FirmSize), earnings before interest and tax (EBIT), firm's total debt (Debt), and sales (Sales). In addition, we also add macroeconomic, credit market, and stock market conditions as additional control variables under filing bankruptcy, such as GDP growth rate (GDPGrowth), credit spread as BAA corporate bond yield minus AAA corporate bond yield (CreditSpread), term spread as 10 year Treasury yield minus 2 year Treasury yield (TermSpread), and CBOE volatility index (VIX). Finally, we also add year dummies to control time fixed effects (Year Dummies) and Fama and French industry dummies to control industry fixed effects $(F \& F$ Industry Dummies). Robust t-statistics are reported in parentheses. *, **, *** denotes the significance level of $10 \%, 5 \%$, and $1 \%$, respectively. 


\subsubsection{DIP Financing}

DIP financing is an important financing source for distressed firms, and it is especially highly related to the success of reorganization. We thus expect that employees would not prevent and may even help push to obtain DIP financing. Hence, firms with strong union power would have a positive impact on the probability of obtaining DIP financing when they are in financial distress. The initial result is reported in column (1) of Table 4, which does not control for the other effects. The coefficient of union power is statistically significant at $1 \%$, implying that an increase in union power raises the probability of obtaining DIP financing. Then, we additionally control for the other characteristics variables in column (1) in the following order: firm characteristics, macroeconomic and credit market conditions, and year and industry dummies. The results are reported in columns (2) to (4), showing that the coefficients only change slightly and all remain statistically significant. Hence, employee force is indeed positively related to the probability of obtaining DIP financing. These results are also in accord with the results for asset sales in the previous section, which illustrate that employees indeed affect conflicts of interest directly related to themselves.

Table 4. Effects of union power on DIP financing

\begin{tabular}{|c|c|c|c|c|}
\hline & (1) & (2) & (3) & (4) \\
\hline Model & Logit & Logit & Logit & Logit \\
\hline Dependent Variable & DIPFinDM & DIPFinDM & DIPFinDM & DIPFinDM \\
\hline \multirow[t]{2}{*}{ UnionPowerFirm } & $1.809 * * *$ & $1.214^{* * *}$ & $1.276^{* * *}$ & $0.804^{*}$ \\
\hline & $(4.789)$ & $(2.922)$ & $(2.951)$ & $(1.720)$ \\
\hline \multirow[t]{2}{*}{ FirmSize } & & $0.284^{* * * *}$ & $0.269 * *$ & $0.264 * * *$ \\
\hline & & $(2.637)$ & $(2.425)$ & $(2.589)$ \\
\hline \multirow[t]{2}{*}{ EBIT } & & $1.110^{* * *}$ & $1.062 * *$ & $0.734 * *$ \\
\hline & & $(2.577)$ & $(2.416)$ & $(2.013)$ \\
\hline \multirow[t]{2}{*}{ Debt } & & $-0.394 * * *$ & $-0.375 * * *$ & $-0.336^{* * *}$ \\
\hline & & $(-3.164)$ & $(-2.936)$ & $(-2.837)$ \\
\hline \multirow[t]{2}{*}{ Sales } & & $0.440 * * *$ & $0.457 * * *$ & $0.365 * * *$ \\
\hline & & $(3.464)$ & $(3.414)$ & $(2.991)$ \\
\hline \multirow[t]{2}{*}{ GDPGrowth } & & & -8.265 & -0.775 \\
\hline & & & $(-0.571)$ & $(-0.049)$ \\
\hline \multirow[t]{2}{*}{ CreditSpread } & & & -0.056 & -0.070 \\
\hline & & & $(-0.236)$ & $(-0.274)$ \\
\hline \multirow[t]{2}{*}{ TermSpread } & & & -0.132 & $-0.218^{*}$ \\
\hline & & & $(-1.353)$ & $(-1.876)$ \\
\hline \multirow[t]{2}{*}{$V I X$} & & & $-0.025^{*}$ & -0.025 \\
\hline & & & $(-1.710)$ & $(-1.632)$ \\
\hline \multirow[t]{2}{*}{ Constant } & $0.441 * * *$ & $0.332^{* * *}$ & $1.207 * * *$ & $1.067 * *$ \\
\hline & $(5.065)$ & $(3.222)$ & (2.834) & $(2.216)$ \\
\hline Year Dummies & No & No & No & Yes \\
\hline$F \& F$ Industry Dummies & No & No & No & Yes \\
\hline$N$ & 787 & 781 & 779 & 779 \\
\hline pseudo $R^{2}$ & 0.027 & 0.085 & 0.097 & 0.146 \\
\hline
\end{tabular}

Note. This table examines the relationship between union power and DIP financing. Hence, the dependent variables is the dummy for DIP financing (DIPFinDM), and one means receiving DIP financing, zero is otherwise. The definitions of other variables can be referred to the illustration of Table 3. Robust t-statistics are reported in parentheses. *,**, *** denotes the significance level of $10 \%, 5 \%$, and $1 \%$, respectively.

\subsubsection{Emerging Success}

When firms are in financial distress, employees are often most concerned about their jobs. They usually behave aggressively to keep their jobs stable and sustain their pay. Hence, the success of emerging from the Chapter 11 reorganization plan is the core goal. We may expect that the higher employee force (proxied by union power), the higher is the probability of emerging successfully. Column (1) of Table 5 reports the Logit regression estimation results for the relationship between union power and the probability of emerging successfully. We find that its coefficient is highly significantly positive at the $1 \%$ level, which is indeed consistent with our inference. We also control for the other potential factors in columns (2) to (4) in the following order: firm 
characteristics, macroeconomic and credit market conditions, and year dummies and industry dummies. Overall, we only observe a marginal reduction in the coefficient estimates of union power, and they are still statistically significant at $1 \%$ in columns (2) and (3) and $10 \%$ in column (4). These results show that union power indeed has positive impacts on the probability of emerging successfully from the reorganization plan. Again, these findings are also in line with those presented in the two previous sections of asset sales and DIP financing, implying that employees indeed care about those interests related to themselves.

Table 5. Effects of union power on emerging success

\begin{tabular}{|c|c|c|c|c|}
\hline & $(1)$ & (2) & (3) & (4) \\
\hline Model & Logit & Logit & Logit & Logit \\
\hline Dependent Variable & EmergingSucDM & EmergingSucDM & EmergingSucDM & EmergingSucDM \\
\hline \multirow[t]{2}{*}{ UnionPowerFirm } & $1.109 * * *$ & $0.920 * * *$ & $0.912 * * *$ & $0.597 *$ \\
\hline & $(3.395)$ & $(2.645)$ & $(2.633)$ & $(1.670)$ \\
\hline \multirow[t]{2}{*}{ FirmSize } & & -0.040 & -0.037 & -0.040 \\
\hline & & $(-1.134)$ & $(-1.023)$ & $(-1.122)$ \\
\hline \multirow[t]{2}{*}{ EBIT } & & 0.090 & 0.099 & 0.041 \\
\hline & & $(0.603)$ & $(0.602)$ & $(0.263)$ \\
\hline \multirow[t]{2}{*}{ Debt } & & 0.023 & 0.020 & 0.027 \\
\hline & & $(0.688)$ & $(0.596)$ & $(0.810)$ \\
\hline \multirow[t]{2}{*}{ Sales } & & $0.081 *$ & 0.077 & $0.094^{*}$ \\
\hline & & (1.666) & (1.508) & (1.734) \\
\hline \multirow[t]{2}{*}{ GDPGrowth } & & & 11.594 & 0.507 \\
\hline & & & $(0.867)$ & $(0.037)$ \\
\hline \multirow[t]{2}{*}{ CreditSpread } & & & $0.483^{* *}$ & $0.452 * *$ \\
\hline & & & $(2.120)$ & (1.963) \\
\hline \multirow[t]{2}{*}{ TermSpread } & & & 0.118 & $0.232 * *$ \\
\hline & & & $(1.346)$ & $(2.395)$ \\
\hline \multirow[t]{2}{*}{$V I X$} & & & $-0.035^{* *}$ & $-0.040 * * *$ \\
\hline & & & $(-2.572)$ & $(-2.877)$ \\
\hline \multirow[t]{2}{*}{ Constant } & $0.590 * * *$ & $0.561 * * *$ & 0.514 & 0.081 \\
\hline & (7.198) & $(5.916)$ & $(1.352)$ & $(0.191)$ \\
\hline Year Dummies & No & No & No & Yes \\
\hline$F \& F$ Industry Dummies & No & No & No & Yes \\
\hline$N$ & 929 & 901 & 846 & 846 \\
\hline pseudo $R^{2}$ & 0.011 & 0.019 & 0.031 & 0.064 \\
\hline
\end{tabular}

Note. This table reports the effects of union power on the success of emerging for those bankruptcy firms. The dependent variable, EmergingSucDM, is the dummy for emerging success (one is successful emerging, zero is otherwise). The definitions of other variables can be referred to the illustration of Table 3. Robust t-statistics are reported in parentheses. *, **, *** denotes the significance level of $10 \%, 5 \%$, and $1 \%$, respectively.

\subsubsection{CEO Replacement}

Agency problems are prevalent in corporate finance, which may result in firms facing financial distress or going bankrupt, even firms with good conditions originally. Take the notorious cases of Enron and WorldCom for example. These were two of the greatest firms in the United States, but their managers engaged in accounting fraud, resulting in the failures of their firms ultimately. The reasons for the failures in such cases are highly related to individual top managers and less related to most other employees. However, the majority of employees may also need to face such difficulties because of the agency problems caused by top managers. Hence, we may expect that employees hope distressed firms dismiss their CEOs, especially when union power is strong. Table 6 shows the Logit regression estimation results. Column (1) reports the univariate result for the relationship between union power and CEO replacement. We find that the coefficient is significantly positive at the $1 \%$ level, implying that the stronger union power, the higher is the probability of CEO replacement. In columns (2) to (4), we control for the other characteristics variables, finding that the coefficients of union power are still positive, and most are still statistically significant at 5\% (the only exception is the coefficient in column (4) is insignificant but still carries the expected positive sign). Overall, the empirical results show the positive impacts of union power on CEO replacement, which again supports our inference that employee force indeed affects conflicts of interest related to employees. 
Table 6. Union power and CEO replacement

\begin{tabular}{|c|c|c|c|c|}
\hline & $(1)$ & (2) & (3) & (4) \\
\hline Model & Logit & Logit & Logit & Logit \\
\hline Dependent Variable & CEOReplaceDM & CEOReplaceDM & CEOReplaceDM & CEOReplaceDM \\
\hline \multirow[t]{2}{*}{ UnionPowerFirm } & $0.948 * * *$ & $0.759^{* *}$ & $0.709^{* *}$ & 0.341 \\
\hline & $(2.997)$ & $(2.225)$ & (2.048) & $(0.947)$ \\
\hline \multirow[t]{2}{*}{ FirmSize } & & -0.016 & -0.019 & -0.013 \\
\hline & & $(-0.328)$ & $(-0.419)$ & $(-0.300)$ \\
\hline \multirow[t]{2}{*}{ EBIT } & & 0.291 & 0.253 & 0.173 \\
\hline & & $(1.456)$ & (1.293) & $(0.972)$ \\
\hline \multirow[t]{2}{*}{ Debt } & & -0.004 & 0.002 & 0.001 \\
\hline & & $(-0.086)$ & $(0.033)$ & $(0.028)$ \\
\hline \multirow[t]{2}{*}{ Sales } & & $0.098^{*}$ & $0.103 *$ & $0.104^{* *}$ \\
\hline & & (1.884) & $(1.852)$ & $(2.066)$ \\
\hline \multirow[t]{2}{*}{ GDPGrowth } & & & 0.523 & -8.940 \\
\hline & & & $(0.038)$ & $(-0.638)$ \\
\hline \multirow[t]{2}{*}{ CreditSpread } & & & 0.295 & 0.296 \\
\hline & & & (1.331) & (1.311) \\
\hline \multirow[t]{2}{*}{ TermSpread } & & & -0.074 & 0.038 \\
\hline & & & $(-0.843)$ & $(0.400)$ \\
\hline \multirow[t]{2}{*}{ VIX } & & & $-0.038^{* * *}$ & $-0.044 * * *$ \\
\hline & & & $(-2.894)$ & $(-3.253)$ \\
\hline \multirow[t]{2}{*}{ Constant } & $0.534 * * *$ & $0.483 * * *$ & $1.072^{* * *}$ & 0.575 \\
\hline & $(6.508)$ & $(4.990)$ & $(2.773)$ & $(1.350)$ \\
\hline Year Dummies & No & No & No & Yes \\
\hline$F \& F$ Industry Dummies & No & No & No & Yes \\
\hline$N$ & 910 & 884 & 830 & 830 \\
\hline pseudo $R^{2}$ & 0.008 & 0.019 & 0.028 & 0.061 \\
\hline
\end{tabular}

Note. This table reports the effects of union power on the success of emerging. The dependent variable, EmergingSucDM, is the dummy for emerging success (one is yes, zero is otherwise). The definitions of other variables can be referred to the illustration of Table 3 . Robust t-statistics are reported in parentheses. $*, * *, * * *$ denotes the significance level of $10 \%, 5 \%$, and $1 \%$, respectively.

\subsubsection{Costs of Bankruptcy Resolutions}

Bankruptcy resolution is often complicated and incurs considerable fees and time. How to deal with distressed firms more efficiently includes choosing a Chapter 7 liquidation plan or a Chapter 11 reorganization plan. Further, employees may again behave aggressively to protect their jobs and pay. However, they may also behave collaboratively to face the financial distress with other stakeholders because of their potential emotional connection with the firm. Hence, the impacts of employees on the costs of bankruptcy resolution may be positive or negative because of these two side effects. Table 7 reports the empirical results: the costs of time in columns (1) and (2) and the costs of fees in columns (3) and (4). We find that only the coefficient in column (1) is positive and statistically significant at $10 \%$, which is consistent with our expectation about these two side effects.

Table 7. Effects of union power on the costs of bankruptcy resolution

\begin{tabular}{lcccc}
\hline & $(1)$ & $(2)$ & $(3)$ & $(4)$ \\
\hline Model & OLS & OLS & OLS & OLS \\
Dependent Variable & CostBKTime & CostBKTime & CostBKFee & CostBKFee \\
\hline UnionPowerFirm & $114.691^{*}$ & -5.860 & 50.679 & 2.264 \\
& $(1.779)$ & $(-0.084)$ & $(1.162)$ & $(0.086)$ \\
FirmSize & & $0.008^{*}$ & & -0.001 \\
& & $(1.842)$ & $(-0.400)$ \\
EBIT & & $-0.025^{* *}$ & $-0.049^{* * *}$ \\
& & $(-1.967)$ & $(-2.838)$ \\
Debt & -0.006 & $0.005^{* *}$ \\
Sales & & $(-1.400)$ & $(2.017)$ \\
GDPGrowth & $0.003^{*}$ & & $0.009^{* *}$ \\
& & $(1.720)$ & $(2.499)$ \\
\end{tabular}




\begin{tabular}{|c|c|c|c|c|}
\hline CreditSpread & & $\begin{array}{l}-43.713 \\
(-0.785)\end{array}$ & & $\begin{array}{l}11.504 \\
(0.662)\end{array}$ \\
\hline TermSpread & & $\begin{array}{c}-60.223 * * * \\
(-2.978)\end{array}$ & & $\begin{array}{c}-15.682 * \\
(-1.690)\end{array}$ \\
\hline VIX & & $\begin{array}{c}3.890 \\
(1.370)\end{array}$ & & $\begin{array}{c}0.255 \\
(0.223)\end{array}$ \\
\hline Constant & $\begin{array}{c}497.146 * * * \\
(24.590)\end{array}$ & $\begin{array}{c}544.759 * * * \\
(5.238)\end{array}$ & $\begin{array}{c}48.692^{* * * *} \\
(5.723)\end{array}$ & $\begin{array}{l}-34.378 \\
(-1.256)\end{array}$ \\
\hline Year Dummies & No & Yes & No & Yes \\
\hline$F \& F$ Industry Dummies & No & Yes & No & Yes \\
\hline$N$ & 943 & 859 & 150 & 150 \\
\hline Adj. $R^{2}$ & 0.002 & 0.050 & 0.010 & 0.539 \\
\hline
\end{tabular}

Note. This table reports the effects of union power on the costs of bankruptcy resolution for those bankruptcy firms. We construct two variables to measure these costs. The first one is the length of time for bankruptcy resolution (CostBKTime), and the second one is the payment fee during the filing process (CostBKFee). The definitions of other variables can be referred to the illustration of Table 3. Robust $\mathrm{t}$-statistics are reported in parentheses. $*, * *, * * *$ denotes the significance level of $10 \%, 5 \%$, and $1 \%$, respectively.

\subsection{Impacts of Union Power on the Conflicts of Interest Unrelated to Employees}

In addition to conflicts of interest directly related to employees, some conflicts of interest are unrelated to them. For example, choosing a method of bankruptcy resolution (i.e., prepackage, prenegotiation, or free-fall) has no relation with the interests of employees, and therefore we would expect no statistically significant relationships between union power and methods of bankruptcy resolution for distressed firms. Table 8 shows the Logit regression results to examine the impacts of union power on these three methods of bankruptcy resolution. Columns (1) to (6) of Table 8 show that all the coefficients are insignificant regardless of whether we add the set of control variables. These results support our inference that employees are only concerned about the interests related to themselves.

Table 8. Union power on the choices of bankruptcy resolution methods

\begin{tabular}{|c|c|c|c|c|c|c|}
\hline & $(1)$ & (2) & (3) & (4) & $(5)$ & (6) \\
\hline Model & Logit & Logit & Logit & Logit & Logit & Logit \\
\hline Dependent Variable & \multicolumn{2}{|c|}{ ChoiceOfPackDM } & \multicolumn{2}{|c|}{ ChoiceOfNegoDM } & \multicolumn{2}{|c|}{ ChoiceOfFrFaDM } \\
\hline \multirow[t]{2}{*}{ UnionPowerFirm } & -0.326 & -0.056 & -0.328 & -0.163 & 0.347 & 0.139 \\
\hline & $(-0.726)$ & $(-0.109)$ & $(-0.936)$ & $(-0.409)$ & (1.169) & $(0.398)$ \\
\hline \multirow[t]{2}{*}{ FirmSize } & & -0.233 & & $-0.223 * *$ & & $0.246^{* * *}$ \\
\hline & & $(-0.961)$ & & $(-2.487)$ & & $(2.676)$ \\
\hline \multirow[t]{2}{*}{ EBIT } & & 1.484 & & -0.071 & & -0.157 \\
\hline & & (1.165) & & $(-0.359)$ & & $(-0.707)$ \\
\hline \multirow[t]{2}{*}{ Debt } & & 0.146 & & $0.242 * *$ & & $-0.254 * * *$ \\
\hline & & $(0.885)$ & & $(2.478)$ & & $(-2.676)$ \\
\hline \multirow[t]{2}{*}{ Sales } & & -0.045 & & $-0.162 * *$ & & $0.149^{* *}$ \\
\hline & & $(-0.425)$ & & $(-2.358)$ & & (2.404) \\
\hline \multirow[t]{2}{*}{ GDPGrowth } & & 19.089 & & -14.216 & & 9.209 \\
\hline & & $(0.918)$ & & $(-0.914)$ & & $(0.657)$ \\
\hline \multirow[t]{2}{*}{ CreditSpread } & & -0.331 & & -0.159 & & 0.148 \\
\hline & & $(-0.592)$ & & $(-0.657)$ & & $(0.640)$ \\
\hline \multirow[t]{2}{*}{ TermSpread } & & $0.333^{* *}$ & & 0.110 & & $-0.239 * *$ \\
\hline & & $(2.153)$ & & (1.009) & & $(-2.465)$ \\
\hline \multirow[t]{2}{*}{$V I X$} & & $-0.061 * * *$ & & 0.000 & & 0.022 \\
\hline & & $(-2.590)$ & & $(0.027)$ & & (1.643) \\
\hline \multirow[t]{2}{*}{ Constant } & $-2.113 * * *$ & -0.397 & $-1.381 * * *$ & $-0.915 * *$ & 0.797 *** & -0.213 \\
\hline & $(-17.296)$ & $(-0.518)$ & $(-14.530)$ & $(-1.971)$ & $(9.711)$ & $(-0.503)$ \\
\hline Year Dummies & No & Yes & No & Yes & No & Yes \\
\hline$F \& F$ Industry Dummies & No & Yes & No & Yes & No & Yes \\
\hline$N$ & 967 & 883 & 967 & 883 & 967 & 883 \\
\hline pseudo $R^{2}$ & 0.001 & 0.113 & 0.001 & 0.037 & 0.001 & 0.059 \\
\hline
\end{tabular}

Note. This table examines whether union power affects the choice of bankruptcy resolution method, including the dummies of pre-packaged cases (ChoiceOfPackDM), pre-negotiated cases (ChoiceOfNegoDM), and free fall cases (ChoiceOfFrFaDM). All of these dependent variables with value one means yes, and zero is otherwise. The definitions of other variables can be referred to the illustration of Table 3. Robust t-statistics are reported in parentheses. *, **, *** denotes the significance level of $10 \%, 5 \%$, and $1 \%$, respectively. 
Many conflicts of interest exist among stakeholders, and some are only related to certain stakeholders such as creditors and debtors. For example, the main conflict of interest for them should be APR violations, which mean a loss for secured creditors. However, as this is unrelated to the interests of employees, we may expect such a conflict having no relationship with employees. In addition to APR violations, we should observe identical findings for the other dimensions such as agent assignment for equity-holders, agent assignment for secured creditors, agent assignment for unsecured creditors, and the behavior of forum shopping. We adopt OLS and the Logit regression model to examine this issue (see Table 9). Consistent with our expectations, we find that the impacts of union power on all six measures of conflicts of interest between creditors and debtors are insignificant, showing again that employees are only concerned about conflicts of interest related to themselves instead of conflicts unrelated to themselves.

Table 9. Effects of union power on the conflicts of interest between creditor and debtor

\begin{tabular}{|c|c|c|c|c|c|c|}
\hline & $(1)$ & $(2)$ & (3) & (4) & (5) & (6) \\
\hline Model & OLS & Logit & Logit & Logit & Logit & Logit \\
\hline \multirow[t]{2}{*}{ Dependent Variable } & ConflictsAPR & ConflictsAPR & ConflictsCEq & ConfilictsClA & ConflictsCred & ConfilictsSho \\
\hline & Degr & $D M$ & $u D M$ & $g D M$ & $D M$ & $p D M$ \\
\hline \multirow[t]{2}{*}{ UnionPowerFirm } & -2.402 & -0.952 & -0.613 & -0.232 & -0.147 & 0.348 \\
\hline & $(-1.030)$ & $(-0.697)$ & $(-0.997)$ & $(-0.120)$ & $(-0.298)$ & (1.009) \\
\hline \multirow[t]{2}{*}{ FirmSize } & 0.064 & 0.111 & $0.076^{*}$ & 0.629 & $0.218^{*}$ & 0.018 \\
\hline & $(0.467)$ & $(0.638)$ & (1.715) & (1.285) & $(1.836)$ & $(0.454)$ \\
\hline \multirow[t]{2}{*}{ EBIT } & 1.440 & 1.083 & -0.021 & -0.004 & -0.510 & -0.039 \\
\hline & $(0.801)$ & $(0.450)$ & $(-0.067)$ & $(-0.004)$ & $(-1.339)$ & $(-0.293)$ \\
\hline \multirow[t]{2}{*}{ Debt } & -0.219 & -0.188 & -0.064 & -0.786 & $-0.217 * *$ & -0.022 \\
\hline & $(-0.849)$ & $(-0.745)$ & $(-1.436)$ & $(-1.437)$ & $(-1.992)$ & $(-0.544)$ \\
\hline \multirow[t]{2}{*}{ Sales } & 0.115 & 0.059 & 0.009 & $4.423 * * *$ & $0.330^{* *}$ & 0.045 \\
\hline & $(0.964)$ & $(0.864)$ & $(0.458)$ & $(2.690)$ & $(2.081)$ & (1.496) \\
\hline \multirow[t]{2}{*}{ GDPGrowth } & 201.990 & $267.44 * * *$ & -15.900 & 37.051 & 7.194 & 5.598 \\
\hline & $(1.054)$ & $(2.677)$ & $(-0.723)$ & $(0.933)$ & $(0.415)$ & $(0.399)$ \\
\hline \multirow[t]{2}{*}{ CreditSpread } & 0.987 & 1.417 & $0.679 *$ & 0.758 & 0.253 & $0.463^{*}$ \\
\hline & $(1.115)$ & $(1.534)$ & (1.774) & (1.206) & $(0.716)$ & $(1.960)$ \\
\hline \multirow[t]{2}{*}{ TermSpread } & 0.481 & -0.137 & -0.188 & -0.609 & $-0.240 *$ & $-0.264 * * *$ \\
\hline & $(0.616)$ & $(-0.236)$ & $(-1.324)$ & $(-1.423)$ & $(-1.849)$ & $(-2.734)$ \\
\hline \multirow[t]{2}{*}{$V I X$} & 0.014 & 0.114 & $-0.073 * * *$ & -0.027 & 0.001 & 0.001 \\
\hline & $(0.197)$ & $(1.436)$ & $(-3.150)$ & $(-0.615)$ & $(0.052)$ & $(0.051)$ \\
\hline \multirow[t]{2}{*}{ Constant } & -1.656 & $-8.418^{* *}$ & $-1.398 *$ & $2.151^{*}$ & 0.551 & $0.987 * *$ \\
\hline & $(-0.388)$ & $(-2.059)$ & $(-1.903)$ & (1.749) & $(0.975)$ & $(2.314)$ \\
\hline Year Dummies & Yes & Yes & Yes & Yes & Yes & Yes \\
\hline$F \& F$ Industry Dummies & Yes & Yes & Yes & Yes & Yes & Yes \\
\hline$N$ & 94 & 75 & 775 & 234 & 850 & 882 \\
\hline adj. $R^{2}$ & -0.150 & & & & & \\
\hline pseudo $R^{2}$ & & 0.154 & 0.099 & 0.331 & 0.080 & 0.046 \\
\hline
\end{tabular}

Note. This table examines the impacts of union power on the conflicts of interests between creditor and debtor for those bankruptcy firms. As the interest of employees should be different to those of creditor and debtor, we expect there are no effects of union power on such interest conflicts. We construct six measurements for such potential interest conflicts only between creditor and debtor, including degree of absolute priority rule violations (ConflictsAPRDegr), dummy for absolute priority rule violations (ConflictsAPRDM), agent assignment for equity holder (ConflictsCEquDM), agent assignment for secured creditor (ConfilictsClAgDM), agent assignment for unsecured creditor (ConflictsCredDM), and dummy for forum shopping (ConfilictsShopDM). The definitions of other variables can be referred to the illustration of Table 3. Robust t-statistics are reported in parentheses. *, **, *** denotes the significance level of $10 \%, 5 \%$, and $1 \%$, respectively.

\subsection{Impacts of Union Power on the Firms' Long Term Performance after Emerging}

Even distressed firms can emerge successfully when using a Chapter 11 reorganization plan. However, this does not mean that they have removed all burdens and moved to a healthy situation completely. They may still face the burden of salaries or pension funds, interest expenses from creditors, or legal fees. For example, as shown in the GM case at the beginning of this paper, the burden of salaries and pension funds hampers long-term performance and may result in bankruptcy again. For those firms with strong union power such as the case of 
GM, this will also increase the probability of refiling for bankruptcy within five years of emerging successfully. Hence, we here examine the impact of union power on long-term performance by using the dummy for refiling for bankruptcy within five years instead of the common financial ratio. Table 10 reports the empirical results. We construct two dummy variables depending on the time length of refiling for bankruptcy after emerging successfully: (i) refiling again or not and (ii) refiling again within five years. Columns (1) and (3) are the univariate regression results without any control variables and columns (2) and (4) control for the sets of firm characteristics, macroeconomic and credit market conditions, and time and industry dummies. We find that all the coefficients of union power are positive and statistically significant at $1 \%$ in columns (1) to (3) and $5 \%$ in column (4), implying the positive impacts of union power on the probability of refiling for bankruptcy. These results also correspond to our inference that firms with strong union power may have a higher burden from their employees, which may ultimately result in filing for bankruptcy in the future.

Table 10. Union power on the long term performance after emerging: refile bankruptcy or not

\begin{tabular}{|c|c|c|c|c|}
\hline & (1) & (2) & (3) & (4) \\
\hline Model & Logit & Logit & Logit & Logit \\
\hline Dependent Variable & RefileDM & RefileDM & Refile 5DM & Refile $5 D M$ \\
\hline \multirow[t]{2}{*}{ UnionPowerFirm } & $1.438 * * *$ & $1.256^{* * *}$ & $1.383 * * *$ & $1.156^{* *}$ \\
\hline & $(4.413)$ & $(2.818)$ & $(3.722)$ & $(2.289)$ \\
\hline \multirow[t]{2}{*}{ FirmSize } & & $-0.325^{* * *}$ & & $-0.453 * *$ \\
\hline & & $(-2.660)$ & & $(-2.417)$ \\
\hline \multirow[t]{2}{*}{ EBIT } & & $0.913^{*}$ & & 0.772 \\
\hline & & (1.779) & & $(1.211)$ \\
\hline \multirow[t]{2}{*}{ Debt } & & $0.239 * *$ & & $0.317 * *$ \\
\hline & & $(2.526)$ & & $(2.501)$ \\
\hline \multirow[t]{2}{*}{ Sales } & & -0.015 & & -0.027 \\
\hline & & $(-0.322)$ & & $(-0.402)$ \\
\hline \multirow[t]{2}{*}{ GDPGrowth } & & -0.603 & & 2.167 \\
\hline & & $(-0.033)$ & & $(0.113)$ \\
\hline \multirow{2}{*}{ CreditSpread } & & $0.619^{*}$ & & 0.106 \\
\hline & & $(1.782)$ & & $(0.237)$ \\
\hline \multirow[t]{2}{*}{ TermSpread } & & $-0.265^{*}$ & & $-0.318 * *$ \\
\hline & & $(-1.954)$ & & $(-2.026)$ \\
\hline \multirow[t]{2}{*}{$V I X$} & & $-0.075^{* * *}$ & & $-0.054 * *$ \\
\hline & & $(-3.636)$ & & $(-2.294)$ \\
\hline \multirow[t]{2}{*}{ Constant } & $-2.080 * * *$ & $-1.998 * * *$ & $-2.494 * * *$ & $-1.207^{*}$ \\
\hline & $(-17.910)$ & $(-2.971)$ & $(-18.120)$ & $(-1.685)$ \\
\hline Year Dummies & No & Yes & No & Yes \\
\hline$F \& F$ Industry Dummies & No & Yes & No & Yes \\
\hline$N$ & 967 & 864 & 953 & 718 \\
\hline Adj. $R^{2}$ & 0.022 & 0.135 & 0.019 & 0.127 \\
\hline
\end{tabular}

Note. This table reports the effects of union power on the long term performance after emerging from last filing bankruptcy. We construct two categories variables to measure these performance. The first one is whether this film refile bankruptcy again after last filing (RefileDM), and the second one is whether this film refile bankruptcy again in five years after last filing (Refile5DM). The definitions of other variables can be referred to the illustration of Table 3. Robust t-statistics are reported in parentheses. *, **, *** denotes the significance level of $10 \%$, $5 \%$, and $1 \%$, respectively.

\section{Conclusion}

The presented findings contribute to the field's understanding of the various forces of stakeholders acting on conflicts of interest when firms are in financial distress, particularly the role of employees. Our empirical results show that for those firms with stronger union power, employees aggressively engage in conflicts of interest related to themselves as well as raise the firms' probability of refiling for bankruptcy in the future. From a policy perspective, these results suggest that balancing employment rights and firm performance is an important issue. Further research should investigate how to avoid such conflicts of interest and maximize firm value. Overall, we not only contribute to the field of finance, but also add novel findings on the system of unions in the field of labor economics and the system of bankruptcy in the field of law. 


\section{References}

Abowd, J. M. (1989). The effect of wage bargains on the stock market value of the firm. The American Economic Review, 79(4), 774-800. http://www.jstor.org/stable/1827932

Acharya, V. V., Bharath, S. T., \& Srinivasan, A. (2007). Does industry-wide distress affect defaulted firms? Evidence from creditor recoveries. Journal of Financial Economics, 85(3), 787-821. http://dx.doi.org/10.1016/j.jfineco.2006.05.011

Ayotte, K. M., \& Morrison, E. R. (2009). Creditor control and conflict in Chapter 11. Journal of Legal Analysis, 1(2), 511-551. https://doi.org/10.1093/jla/1.2.511

Betker, B. L. (1995). Management's incentives, equity's bargaining power, and deviations from absolute priority in Chapter 11 bankruptcies. Journal of Business, 161-183. http://dx.doi.org/10.1086/296659

Bronars, S. G., \& Deere, D. R. (1991). The threat of unionization, the use of debt, and the preservation of shareholder wealth. The Quarterly Journal of Economics, 106(1), 231-254. https://doi.org/10.2307/2937914

Carrizosa, R., \& Ryan, S. G. (2013). Conservatism, covenants, and recovery rates. Working paper. https://papers.ssrn.com/sol3/papers.cfm?abstract_id=2197513

Chen, S. S., Chen, Y. S., \& Wang, Y. (2015). Does labor power affect the likelihood of a share repurchase?. Financial Management, 44(3), 623-653. https://doi.org/10.1111/fima.12072

DeAngelo, H., \& DeAngelo, L. (1991). Union negotiations and corporate policy: A study of labor concessions in the domestic steel industry during the 1980s. Journal of Financial Economics, 30(1), 3-43. https://doi.org/10.1016/0304-405X(91)90025-F

DeAngelo, H., DeAngelo, L., \& Skinner, D. J. (1994). Accounting choice in troubled companies. Journal of Accounting and Economics, 17(1), 113-143. https://doi.org/10.1016/0165-4101(94)90007-8

Demiroglu, C., \& James, C. (2015). Bank loans and troubled debt restructurings. Journal of Financial Economics, 118(1), 192-210. https://doi.org/10.1016/j.jfineco.2015.01.005

Donovan, J., Frankel, R. M., \& Martin, X. (2015). Accounting conservatism and creditor recovery rate. The Accounting Review, 90(6), 2267-2303. https://doi.org/10.2308/accr-51045

Faleye, O., Mehrotra, V., \& Morck, R. (2006). When labor has a voice in corporate governance. Journal of Financial and Quantitative Analysis, 41(3), 489-510. https://doi.org/10.1017/S0022109000002519

Gilson, S. C. (1989). Management turnover and financial distress. Journal of Financial Economics, 25(2), 241-262. https://doi.org/10.1016/0304-405X(89)90083-4

Gilson, S. C. (1990). Bankruptcy, boards, banks, and blockholders: Evidence on changes in corporate ownership and control when firms default. Journal of Financial Economics, 27(2), 355-387. https://doi.org/10.1016/0304-405X(90)90060-D

Hanka, G. (1998). Debt and the terms of employment. Journal of Financial Economics, 48(3), $245-282$. https://doi.org/10.1016/S0304-405X(98)00012-9

Hirsch, B. T. (1991). Union coverage and profitability among US firms. The Review of Economics and Statistics, 69-77. http://www.jstor.org/stable/2109688

Hotchkiss, E. S., \& Mooradian, R. M. (1997). Vulture investors and the market for control of distressed firms. Journal of Financial Economics, 43(3), 401-432. https://doi.org/10.1016/S0304-405X(96)00900-2

Hotchkiss, E. S., Strömberg, P., \& Smith, D. C. (2014). Private equity and the resolution of financial distress. Working paper. https://papers.ssrn.com/sol3/papers.cfm?abstract_id=1787446

Huang, Q., Jiang, F., Lie, E., \& Que, T. (2017). The effect of labor unions on CEO compensation. Journal of Financial and Quantitative Analysis, 52(2), 553-582. https://doi.org/10.1017/S0022109017000072

Ivashina, V., Iverson, B., \& Smith, D. C. (2016). The ownership and trading of debt claims in Chapter 11 restructurings. Journal of Financial $\quad$ Economics, $119(2), \quad 316-335$. https://doi.org/10.1016/j.jfineco.2015.09.002

James, C. (1995). When do banks take equity in debt restructurings?. The Review of Financial Studies, 8(4), 1209-1234. https://doi.org/10.1093/rfs/8.4.1209

Jiang, W., Li, K., \& Wang, W. (2012). Hedge funds and Chapter 11. The Journal of Finance, 67(2), 513-560. http://hdl.handle.net/10.1111/j.1540-6261.2012.01724.x 
Klasa, S., Maxwell, W. F., \& Ortiz-Molina, H. (2009). The strategic use of corporate cash holdings in collective bargaining with labor unions. Journal of Financial Economics, 92(3), 421-442. https://doi.org/10.1016/j.jfineco.2008.07.003

Lee, D. S., \& Mas, A. (2012). Long-run impacts of unions on firms: New evidence from financial markets, 1961-1999. The Quarterly Journal of Economics, 127(1), 333-378. https://doi.org/10.1093/qje/qjr058

Matsa, D. A. (2010). Capital structure as a strategic variable: Evidence from collective bargaining. The Journal of Finance, 65(3), 1197-1232. https://doi.org/10.1111/j.1540-6261.2010.01565.x

Ruback, R. S., \& Zimmerman, M. B. (1984). Unionization and profitability: Evidence from the capital market. Journal of Political Economy, 92(6), 1134-1157. https://doi.org/10.1086/261278

Schmalz, M. C. (2013). Managing human capital risk. Working Paper. https://doi.org/10.2139/ssrn.2254025

Weiss, L. A., \& Wruck K. H. (1998). Information problems, conflicts of interest, and asset stripping: Chapter 11 's failure in the case of Eastern Airlines. Journal of Financial Economics, 48(1), 55-97. https://doi.org/10.1016/S0304-405X(98)00004-X

\section{Copyrights}

Copyright for this article is retained by the author(s), with first publication rights granted to the journal.

This is an open-access article distributed under the terms and conditions of the Creative Commons Attribution license (http://creativecommons.org/licenses/by/4.0/). 